\title{
O malarce, która „osiągnęła w szkicu i rysunku poziom wyższy od jakiejkolwiek innej artystki naszych czasów"* Autoportret Sofonisby Anguissoli
}

\section{Abstract}

On a female painter who "achieved in sketch and drawing a level higher than any other female artist of our time" Sofonisba Anguissola's self-portrait

The article is about the life and artworks of an Italian renaissance female painter, Sofonisba Anguissola. Its objective is to compare her self-portraits in three different layers- the first one concentrates on formal matters such as composition, colours and theme, the second layer steps out from the frame of the painting and delves into cultural aspects of her life and tries to understand her works in that context. And the third, final layer tries to reveal her own motivations and dreams and looks at her, an artist from those times, through the eyes of a modern woman who, even though living almost 500 years later, thanks to impermanence of art can still feel and experience similar emotions. By analysing her self-portraits, it is possible to see different stages of her life: youth, adulthood and elderly years. Each portrait corresponds to a different

* Dokładny cytat z Żywotów Vasariego (1568: s. 174) w języku włoskim brzmi w ten sposób: (Sofonisba) ,ha con più studio e con miglior grazia che altra donna de' tempi nostri faticato dietro alle cose del disegno". 
type of sensibility, aspirations and desires: from passionate young artist nearly stepping into her professional life, through matured and self-assured woman, till an old matron fulfilled by her life and expecting the end with peace. This great painter not only laid out the style of female portraits for the next hundreds of years but also left us with something like a portrait- journal which can lead to transcendental and timeless perspective into art.

Key words: Sofonisba Anguissola, renaissance, female painter, self-portrait, Italian art

Słowa kluczowe: Sofonisba Anguissola, renesans, malarka, autoportret, sztuka włoska

Le donne son venute in eccellenza di ciascun'arte ov'hanno posto cura.

Tymi słowami, cytowanymi za renesansowym poetą Ludovico Ariosto, słynny włoski historiograf Giorgio Vasari kończy opis żywota kilku współczesnych mu artystek i choć główna część jego wywodu poświęcona została twórczości bolońskiej rzeźbiarki Properzii de' Rossi, to w zakończeniu rozdziału Vasari nie omieszkał umieścić kilku istotnych faktów dotyczących kobiety, która, w jego ocenie, osiągnęła w szkicu i rysunku poziom wyższy od jakiejkolwiek innej artystki wówczas działającej (Vasari 1568: 172). Mowa o, mającej w chwili druku drugiego wydania Żywotów 33 lata, Sofonisbie Anguissoli - pochodzącej z arystokratycznego rodu ambitnej, młodej malarce.

Mało kto wie, że ród Anguissola wydał na świat nie jedną, lecz aż pięć uzdolnionych artystek ${ }^{1}$ i choć nie wszystkie są tak rozpoznawalne jak bohaterka niniejszego artykułu, to każda z nich już od najmłodszych lat przejawiała niewątpliwy talent malarski, odziedziczony zapewne po którymś z rodziców². Dziś, jak wspomniano, najbardziej rozsławioną jest najstarsza z sióstr - Sofonisba. Głowa rodu Amilcare nazwał swoją pierwszą córkę na cześć żyjącej w III wieku p.n.e. kartagińskiej królowej, córki wodza Hazdrubala ${ }^{3}$, który w obronie Kartaginy walczył z Rzymianami w drugiej wojnie punickiej. Sofonisba jako jedna z nielicznych kobiet, tuż obok legendarnej założycielki Kartaginy - Dydony, zapisała się w kartach historii na wiele lat. Być może więc ojciec Anguissoli przeczuwał, że pamięć o jego córce, jako jej imienniczki, również przetrwa.

1 Cztery siostry Sofonisby: Elena, Lucia, Europa i Anna Maria również zostały malarkami. Elena porzuciła później karierę artystyczną i wstąpiła do zakonu. Piąta siostra, Minerva, została nauczycielką i pisarką, a ich jedyny brat, Asdrubale - muzykiem.

2 Zarówno ojciec, Amilcare Anguissola, jak i matka - Bianca Ponzoni, pochodzili z arystokratycznych rodów.

3 Na cześć samego wodza został natomiast nazwany brat dziewcząt - Asdrubale.

208

Fabrica Litterarum Polono-Italica | 2021, nr 1 (3) 
Historia jej żywota jest już przez badaczy dość dobrze opisana4, w związku z czym, w niniejszym artykule zostaną przywołane jedynie najistotniejsze wydarzenia dotyczące jej biografii, natomiast główna część zostanie poświęcona malarstwu, w sposób szczególny roli autoportretu, gdyż stanowi on zdecydowaną większość wszystkich realizacji Sofonisby i jest tym samym istotnym elementem jej twórczości. Autoportrety Sofonisby, choć rozproszone są dziś w muzeach na całym świecie, a historia ich wędrówek pozostaje $w$ wielu przypadkach wciąż nieodgadniona (tak jak ma to również miejsce w kontekście obrazu z Muzeum Zamkowego w Łańcucie) $)^{5}$, stanowią fascynujący powód dociekań naukowych, który pomimo upływu lat nieustannie inspiruje i zachęca do odkrywania i zgłębiania twórczości tej wyjątkowej artystki. Swoje pierwsze zetknięcie z twórczością Sofonisby pamiętam bardzo dobrze. Jako rozpoczynająca dopiero swoją naukę studentka historii sztuki, pierwszy raz spotkałam się wówczas z kobietą malarką i jej autoportretem tak genialnym, że od spojrzenia zamieszczonej na nim postaci trudno oderwać wzrok.

Celem niniejszego artykułu jest próba zestawienia najciekawszych - w mojej, subiektywnej opinii - autoportretów renesansowej malarki z trzech różnych okresów jej życia oraz spojrzenie na nie z kilku różnych perspektyw. Pierwsza dotyczyć będzie typowo malarskich rozwiązań dzieła - a więc techniki, faktury, kolorystyki, kadrowania, sposobu zaaranżowania kompozycji i przedstawienia osób oraz przedmiotów - jednym słowem, wszystkiego tego, co interesuje historyka sztuki z formalnego punktu widzenia. Druga perspektywa polega na wyjściu nieco poza ramy obrazu. Dokonując wstępnej analizy symbolicznych aspektów dzieła w kontekście kulturowym i ówczesnych standardów społecznych, spróbuję odpowiedzieć na pytanie o istotę dzieła. Wreszcie, po trzecie, podejmę próbę zrozumienia motywacji, aspiracji i założeń samej malarki. Będzie to spojrzenie na kobietę okiem drugiej kobiety i choć dzieli nas kilkaset lat, dzięki nieprzemijalności sztuki możemy stanąć niemal twarzą w twarz i spojrzeć sobie głęboko w oczy.

Przenieśmy się teraz na moment do północnych Włoch i urokliwej Cremony w Lombardii - rozległej, malowniczej krainy, która mimo swych burzliwych losów i przechodzenia spod panowania jednych najeźdźców w ręce drugich, przez wieki, w sposób niezwykły, nie tylko wzbogacała dorobek kulturowy naszej cywilizacji wspaniałymi zabytkami, ale także wydała na świat wielu znamienitych artystów,

4 Do najważniejszych zaliczyć można: Caroli 1994; Pizzagalli 2003; Borghini 2006.

5 Przypuszcza się, że obraz trafił do Łańcuta dzięki Izabeli Lubomirskiej, choć do dziś niepewne jest, gdzie dokładnie został zakupiony. Co ciekawe, bardzo podobny, przypisywany Sofonisbie portret, z nieco innym, szerszym kadrowaniem, został jakiś czas temu sprzedany prywatnemu kolekcjonerowi na licytacji jednego z największych światowych domów aukcyjnych - nowojorskiego Christie's. Przedstawiona na tym portrecie kobieta, mimo nasuwającego się na pierwszy rzut oka podobieństwa do Sofonisby, ma jednak zgoła odmienną urodę - jasnozłote włosy i znacznie pełniejsze policzki.

209

Fabrica Litterarum Polono-Italica | 2021, nr 1 (3) 
począwszy od architektów, rzeźbiarzy czy też malarzy ${ }^{6}$. W połowie XVI wieku, w końcowym etapie wojen włoskich, nastał dla Cremony czas długiego i powodującego powolny upadek panowania Hiszpanów zwieńczony wstąpieniem na tron Filipa II w 1546 roku. Zanim to nastąpiło, Cremona była miejscem ścierania się różnorakich wojsk. Jednak w latach 1526-1546 Republika Wenecka, próbując odeprzeć Hiszpanów, na krótko zapanowała w mieście. To właśnie wtedy, w arystokratycznej rodzinie Anguissolów przyszła na świat Sofonisba. Choć niektóre ze źródeł podają dzień jej narodzin - 2 lutego 1532 roku, część badaczy kwestionuje tę datę (Chadwick 2015: 84). Nieco pewniejsze natomiast jest to, że Sofonisba już jako mała dziewczynka przejawiała zamiłowanie do malarstwa i wykazywała posiadanie wysokich zdolności manualnych, co skutecznie zdawał się pielęgnować jej ojciec - pasjonat sztuki i literatury. Zafascynowany powieścią autorstwa Baltazara Castiglione /l Cortigiano ${ }^{7}$ ochoczo zachęcał zresztą wszystkie swoje dzieci do doskonalenia własnych talentów i podejmowania się takiej pracy, jaką pragną wykonywać (Kuiper 2009). Nie sposób nie wspomnieć tutaj o panujących wówczas, odmiennych nieco od dzisiejszych, standardach kulturowych, także i tych, dotyczących kwestii zawodów wykonywanych przez kobiety. Problem ten, choć bardzo istotny, jest z całą pewnością zagadnieniem nieco bardziej złożonym, wielowątkowym i wymagającym dużo dokładniejszego opracowania niż takiego, na jakie mogę sobie pozwolić w zaledwie kilku zdaniach. Faktem jest, że kobiet malarek znamy dziś znacznie mniej niż mężczyzn, a przyczyny tego są różne, zresztą samo zagadnienie, mimo wszystko, jest bardzo niejednoznaczne. Jedni badacze wskazują na kwestie nierówności społecznej i pośrednio obwiniają model społeczny oparty na patriarchacie. Są także i tacy, którzy, zachowując nieco większą powściągliwość w interpretowaniu historii z punktu widzenia współczesności, będą wskazywać także na inne, pomijane niekiedy czynniki, które taki stan rzeczy mogły powodować. By dogłębnie zrozumieć owe kwestie, należałoby przyjąć kilka różnych, adekwatnych do miejsca, czasu i kontekstu, punktów widzenia.

Wracając do bohaterki artykułu, w 1546 roku możni rodzice posłali dwie ze swoich najstarszych córek, Sofonisbę i Helenę, na naukę do jednego z czołowych przedstawicieli kremońskiej elity artystycznej - Bernardino Campiego (Pizzagalli 2003: 25). Choć po około trzech latach Sofonisba kształciła się już u innego mala-

6 Wystarczy choćby wspomnieć o dużej liczbie artystów emigrujących do różnych miejsc Europy na przestrzeni wieków, ale w sposób najaktywniejszy w wieku XVI (jak np. Francesco Borromini, Domenico, Baldassare i Paolo Antonio Fontana, Domenico Merlini), których zwykło nazywać się Komaskowie - od jeziora Como, w pobliżu którego wielu z nich się urodziło.

7 Pełny tytuł brzmi: /l libro del Cortegiano. Ksiqżka o Dworzaninie to ponadczasowe dzieło, oprócz wspaniałego opisu życia dworskiego, wskazuje także na pewne istotne kwestie egzystencjalne, takie jak potrzeba człowieka do samorozwoju i możliwość dążenia do realizacji własnych celów i marzeń.

210

Fabrica Litterarum Polono-Italica | 2021, nr 1 (3) 
rza - Bernardina Gattiego zwanego II Sojaro, to wskazówki Campiego miały zdecydowanie najmocniejsze przełożenie na późniejszą twórczość Anguissoli i wyraźnie widać, że charakterystyczna stylistyka nawiązująca do manieryzmu północnego, która cechuje jego dzieła, towarzyszyć jej będzie już od początków kariery. To właśnie tego pierwszego mistrza i nauczyciela ukazuje jeden z najbardziej rozpoznawalnych obrazów z wczesnego okresu jej twórczości, znajdujący się w Pinakotece Narodowej w Sienie. Campi przedstawiony został w trakcie pracy, przy sztaludze, na której widnieje wizerunek Sofonisby. To z pozoru proste zarówno kompozycyjnie, jak i tematycznie dzieło jakże wymowne jest w swej istocie. Zdaje się pokazywać jeszcze dobitniej, że także sama Anguissola świadoma była ogromnego wpływu, jaki wywarł na nią Campi. Można wręcz pokusić się o twierdzenie, że to właśnie on stworzył, czy też „namalował” ją jako artystkę - dał jej narzędzia i pokazał drogę, którą może podążać. Obraz ten, będący jednocześnie przedstawieniem pierwszego autoportretu Sofonisby, jest - jak się wydaje - także wyrazem podziękowania i uznania dla roli nauczyciela w życiu młodej malarki.

Dalsze losy artystki związane są z jej podróżą do Rzymu w 1554 roku, podczas której poznała między innymi Michała Anioła (Jacobs 1994). To wskutek tego niesamowitego spotkania i dalszej korespondencji tych dwóch, genialnych umysłów, powstał niesamowicie ekspresyjny szkic, tak zwanego płaczącego chłopca. Szkic, którym niemal pół wieku później zachwycił się i dał dzięki niemu upust swojej szaleńczej kreatywności kolejny fenomenalny twórca, formujący już pierwsze podstawy malarstwa doby baroku. Mowa o Caravaggiu i dziele Chłopiec ugryziony przez jaszczurkę. Osiągnąwszy już wówczas na gruncie włoskim sławę, w 1558 roku Sofonisba udała się do Mediolanu. Tam zachwycił się nią książę Alby Ferdynand Álvarez toledański. Dzięki jego poleceniu, już w rok później Sofonisba została zaproszona na dwór hiszpański do króla Filipa II, gdzie następnie jako nadworna dama i nauczycielka sztuki nastoletniej Elżbiety von Valois pracowała przez kolejne lata. Pozostała w Hiszpanii jeszcze przez kilka lat po przedwczesnej śmierci młodej królowej, przez cały okres pobytu na dworze malowała portrety członków królewskiej rodziny.

Zdaje się, że dożywszy niemal 40 lat, Sofonisba nie związała się z żadnym mężczyzną na stałe. W kontekście panujących wówczas konwenansów społecznych tak długie panieństwo było rzeczą niezwykłą. Wart podkreślenia jest również fakt, że malarka podówczas utrzymywała się z własnej pracy twórczej. W 1571 roku sytuacja ta uległa zmianie. Artystka zawarła z arystokratą Fabrizio Moncadą aranżowane małżeństwo ${ }^{8}$. Wspólnie zamieszkali w ojczyźnie Moncady - na Sycylii. Beztroska nie trwała jednak długo i po niespełna 8 latach Sofonisba została wdową. Okoliczności śmierci Fabrizia wciąż nie są do końca wyjaśnione, choć prawdopodobna wydaje się

8 Zamieszkali w miejscowości Paternò, niedaleko Katanii (choć niektórzy autorzy podają, że para mogła także pozostać w Hiszpanii. Zob. Kuiper 2009).

211

Fabrica Litterarum Polono-Italica | 2021, nr 1 (3) 
informacja wskazująca za przyczynę panującą wówczas zarazę, to istnieje także dość szczegółowa relacja o napadzie na statek, którym płynął do Hiszpanii Fabrizio (Gago 2020: 97). Po śmierci męża, w drodze do rodzinnych stron, na statku płynącym do Cremony Sofonisba poznała młodszego o 15 lat kapitana z Genui - Orazia Lomellina. Para wzięła ślub i pozostała w związku przez długie lata. Jego kres wyznaczyła śmierć artystki. W 1625 roku, w Palermo, Anguissola odeszła z tego świata, pozostawiając po sobie wspaniały pomnik artystyczny w postaci dzieł, portretów innych osób, jak i swoich, dzięki którym jej wizerunek przetrwał.

Warto zastanowić się, jakie cechy charakteryzują dzieła Sofonisby? Spoglądając na jej twórczość, nie tylko autoportrety, można wyodrębnić kilka charakterystycznych elementów, które wyróżniają jej styl. Oprócz siebie malowała także członków rodziny - siostry, brata oraz rodziców ${ }^{9}$. Już w pierwszych pracach dostrzec można pewną dozę delikatności i coś, co jest w kontekście opisu dzieł sztuki, ze względu na swą niejednoznaczność, jednym z najmniej odpowiednich określeń, ale mimo to nie sposób się przy okazji opisu jej prac powstrzymać od użycia go. Mowa o wdzięku, który przejawia się zarówno w pozach przedstawionych postaci, taktownych gestach, które te postaci wykonują, ale także w formalnych właściwościach obrazu, takich jak sposób rozłożenia barw, dokładność, a zarazem miękkość w oddaniu wszelkich linii i szczegółów stroju, biżuterii czy innych elementów kompozycyjnych.

Wszystkie omówione wyżej cechy możemy dostrzec w tym niezwykłym, znajdującym się w Muzeum Zamkowym w Łańcucie, autoportrecie (zob. ilustracja nr 1). Na prostokątnym płótnie malarka ukazała się przy pracy, obok sztalugi. Przedstawiona w półpostaci i zwrócona lewym bokiem do widza, delikatnie spogląda na niego z półprofilu. Kobieta o wyraźnych, mocno osadzonych oczach o owalnym kształcie, zadartym lekko nosie, wąskich ustach i młodzieńczej, porcelanowej cerze zdaje się skupiona i spokojna. Jej przenikliwe spojrzenie i harmonijna mimika twarzy sprawiają, że jawi się jako osoba wyważona, pełna powagi. Rudobrązowe włosy spięte są w typową dla tego okresu fryzurę - zebrane w wysoki kok dwa, grube warkocze. Prosty ciemny strój, mimo iż skromny i stonowany kolorystycznie, jest bardzo wyrafinowany. Nie uderza tutaj bogactwo dekoracji i ornamentów sukni czy też pełna przepychu droga tkanina. Znajdująca się z prawej strony bohaterki sztaluga zdradza powstające jeszcze dzieło z przedstawieniem Madonny z Dzieciątkiem. Malarka, trzymając w prawej ręce pędzel i podpierając ją trzymanym w lewej dłoni narzędziem malarskim, zwanym malstokiem, nadaje płótnu ostatnie szlify. Nie jest jednak pewne, czy obraz ten powstał naprawdę, czy też była to tylko kompozycja utworzona na potrzeby omawianego autoportretu.

9 Drugie ze znajdujących się w Polsce dzieł autorstwa Sofonisby znajduje się w Muzeum Narodowym w Poznaniu i przedstawia jej grające w szachy siostry oraz stojącą obok służącą. To niebywałe dzieło, mimo z pozoru lekkiej tematyki, wydaje się posiadać drugie, symboliczne znaczenie. Więcej o jego ukrytej treści w artykule: Gerrard 1994.

212

Fabrica Litterarum Polono-Italica | 2021, nr 1 (3) 


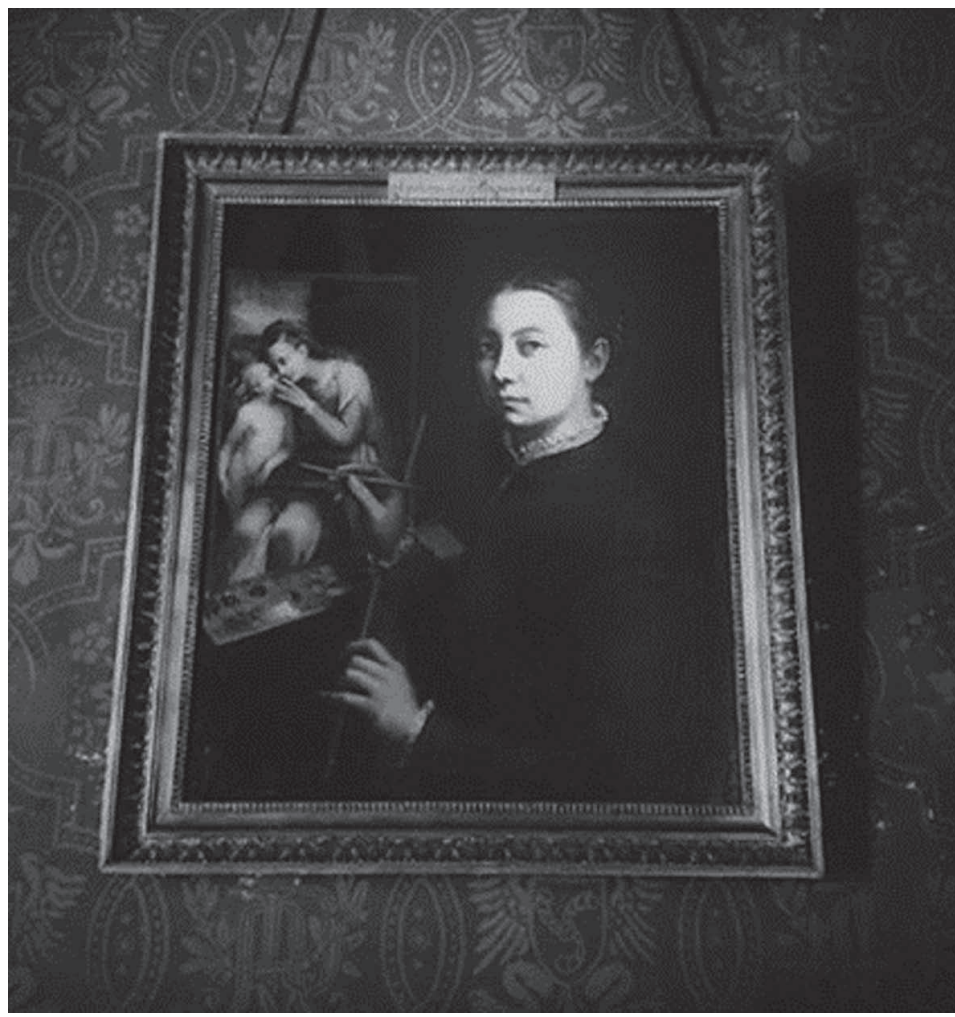

II. 1. Sofonisba Anguissola: Autoportret przy sztaludze (1556), olej na płótnie, $66 \times 57 \mathrm{~cm}$, Zamek w Łańcucie Fot. Magda Morello.

Widzimy tutaj zatem portret młodej, lecz świadomej już swojej wartości artystki, która, będąc pewna swych umiejętności malarskich i możliwości podjęcia się dowolnej tematyki twórczej, prezentuje je niemal wszystkie. Jest zdolna do tworzenia scen religijnych - o czym poświadcza namalowany w tle obraz Madonny, jest także w stanie odwzorować bardzo dobrze anatomię człowieka, o czym przekonuje nas subtelnie przy okazji przedstawienia nagiego Dzieciątka Jezus. Nie jest jej także obce malowanie elementów świata nieożywionego, o czym zapewnia, choć przedstawiona zaledwie częściowo, to jednak w sposób bardzo dokładny, sztaluga, farby oraz narzędzia malarskie. Świadczy to o kolejnej z cech dobrego malarza - niezwykle ważnej zdolności do łączenia i komponowania barw. Skrót perspektywiczny użyty przez Sofonisbę do ukazania siebie na pierwszym planie, tła w postaci sztalugi z obrazem oraz sceny religijnej na płótnie (z podobnym schematem kompozycyjnym, czyli pierwszoplanowymi postaciami oraz rysującym się w tle krajobrazem) jest kolejnym potwierdzeniem jej umiejętności.

213

Fabrica Litterarum Polono-Italica | 2021, nr 1 (3) 
Artystka przedstawiła więc tutaj wachlarz swych kompetencji jako pełnoprawnej malarki i z nienachalną, lecz bardzo subtelną i jak najbardziej uzasadnioną dumą, spogląda na odbiorcę dzieła. W jej spojrzeniu można dostrzec także charakterystyczny blask, towarzyszący niemal każdemu młodemu człowiekowi wkraczającemu w dorosłe życie. Od kobiety bije optymizm i radość. Być może malujący się na jej twarzy uśmiech powstaje na myśl o stojącej dla niej otworem karierze? A ta rzeczywiście nabrała znacznego tempa już w niedalekiej przyszłości - niespełna trzy lata po namalowaniu omawianego autoportretu, Sofonisba przybyła na dwór króla Filipa II i rozpoczęła tam pracę.

Nieco później, około roku 1560, a więc już jako nadworna malarka Filipa II, Sofonisba przedstawiła się w nieco inny sposób - nie jako rozpoczynająca swą karierę, młoda malarka, ale jako dojrzała, spełniona i świadoma swojego szlachetnego urodzenia kobieta. Portret przedstawia ją z półprofilu. Zwrócona lekko w lewą stronę twarz kobiety wypełnia niemal całą powierzchnię niewielkiego (bo o wymiarach zaledwie 36 x $30 \mathrm{~cm}$ ) płótna. Choć w katalogu Muzeum Condé w Chantilly we Francji obraz widnieje pod nazwą Portret kobiety, można przypuszczać, iż jest to autoportret malarki. Świadczy o tym duże podobieństwo w wyglądzie - te same, przenikliwie patrzące na widza, okrągłe, ciemnobrązowe oczy, ta sama, wciąż jeszcze gładka i perłowa cera z wyraźnym rumieńcem, wąskie usta o bladoróżowym zabarwieniu i nieduży, zadarty lekko nos. Zwraca uwagę bogactwo stroju i biżuterii oddane z pieczołowitą dokładnością - misternie ułożone rudobrązowe włosy o złocistym połysku ozdobione są perłowymi spinkami, będącymi prawdopodobnie kompletem z podobnymi, perłowymi kolczykami. Istotnym elementem stroju jest także wysoki, wykonany z jasnej tkaniny i ozdobiony koronką kołnierz, tak zwana kryza, poniżej której gruby, złoty łańcuch wysadzany kamieniami szlachetnymi oplata suknię na wysokości dekoltu.

Portret ten, już po pobieżnych oględzinach, zdaje się mieć zupełnie inny wydźwięk niż poprzedni. Tam - dumna z siebie, lecz pogodna, bardzo młoda jeszcze dziewczyna patrzy z optymizmem w przyszłość - jak gdyby nie mogła się doczekać wszystkich tych wspaniałych przygód, jakie ma przynieść życie. Tutaj - dostojna, lecz nieco zdystansowana kobieta, która tymi samymi oczami spogląda przed siebie już z nieco mniejszym entuzjazmem. Choć jej kariera malarska kwitnie, wyraz jej twarzy sprawia wrażenie, że czegoś jej brakuje. Obraz namalowany został krótko po przyjeździe na dwór hiszpański. Być może więc emocja, która dostrzegalna jest w jej spojrzeniu, to tęsknota za domem i ojczystą Italią? A być może strach przed osamotnieniem i niepewność związana z nowym dla niej światem? Wszystkie te troski mogły towarzyszyć malarce, jak każdej niemal osobie stawiającej czoła nowym wyzwaniom. Choć jeszcze kilka lat wcześniej życie zdawało się ekscytującą wędrówką i kusiło możliwościami - w obliczu zmian, które przynosi, pojawia się obawa, a dotychczas atrakcyjna tajemniczość zmienia się w dręczącą niewiedzę. 
Wspaniałym podsumowaniem tej artystycznej drogi jest ostatni, wykonany przez Anguissolę autoportret. Rok przed śmiercią, w 1624 roku, mającą 92 lata Sofonisbę odwiedził flamandzki malarz Anton van Dyck, który w relacji z wizyty wspomina malarkę jako w pełni sił mentalnych. Jedynym uszczerbkiem zdrowotnym, który sugerował jej sędziwy wiek, był słabnący wzrok (Tanzi 2014). Ostatni autoportret kobiety, znajdujący się dziś w kolekcji Muzeum w Niwie w Danii, namalowany został w 1620 roku. Ukazana w półpostaci, z prawego półprofilu, odziana w ciemną, obszerną suknię i płaszcz kobieta siedzi na drewnianym krześle z profilowanym oparciem. Jej twarz, choć obarczona znakiem czasu, zdradza znajome z poprzednich dzieł cechy urody - delikatne rysy, lekko zadarty nos i węższe nieco wskutek postępującego już wieku usta. Jej cera, mimo że z zaznaczonymi gdzieniegdzie zmarszczkami, jest nadal gładka. Zwracają uwagę te same, głęboko osadzone i przepełnione spokojem, ciemne oczy. O zaawansowanym wieku przypomina dobitnie jedynie fryzura - włosy nie są już tak gęste i błyszczące, a spod zasłoniętej chustą głowy ukazują się gdzieniegdzie cienkie kosmyki o siwym odcieniu. Jako dojrzała kobieta, u progu swojego życia Sofonisba spogląda na nas z poczuciem spełnienia. Zdołała osiągnąć sukces, żyć godnie i w dostatku, a także, jak się zdaje, poślubić prawdziwą miłość. Choć umiera bezdzietnie, pamięć o niej zachowały jej dzieła - a w sposób szczególny autoportrety.

Sofonisbie udało się osiągnąć w życiu zawodowym bardzo dużo, o wiele więcej niż większości kobiet tamtych czasów. Jej wysoka ranga na hiszpańskim dworze, imponujący majątek oraz duże umiejętności malarskie sprawiły, że już za życia cieszyła się ogromną sławą. Niestety, po śmierci pamięć o niej na wiele lat uległa rozproszeniu, a niektóre z jej dzieł przypisywano innym artystom płci męskiej - na przykład Tycjanowi. Jej dzieła potwierdzają jednak, jak dużym poważaniem cieszyła się przez wszystkie niemal lata swej artystycznej drogi. Autoportret przy sztaludze jest wyraźnym podkreśleniem znaczącej roli na zdominowanym wówczas przez mężczyzn rynku sztuki. Późniejsze płótno, powstałe w okresie pracy u Filipa II, pokazuje, iż jej sława sięgała także poza granice Italii. Najpóźniejsze autoportrety są potwierdzeniem spełnienia zarówno zawodowego, jak i osobistego, duchowego.

Anguissola to artystka, która w sposób wyjątkowy urozmaiciła losy światowego malarstwa. Jej styl wyznaczył w portretowym malarstwie kobiecym kierunek na następne kilkaset lat, a uznanie, jakie osiągnęła jeszcze za życia, dorównać może niejednemu artyście płci męskiej. Szczególnie ciekawe są jej autoportrety, będące dokumentem różnych etapów życia malarki, których przykłady zostały wymienione i opisane w niniejszym artykule. Artystka przedstawiała siebie zarówno jako młodą, pełną pasji dziewczynę, rozpoczynającą karierę początkującą malarkę, dojrzałą i świadomą swych walorów kobietę, jak i jako sędziwą matronę, spełnioną i w gotowości oczekującą na śmierć. Różne stadia wieku informują nas także o odmiennych pragnieniach, marzeniach i aspiracjach artystki i jak w zwierciadle ukazują

215

Fabrica Litterarum Polono-Italica | 2021, nr 1 (3) 
odpowiadające danemu okresowi cechy osobowości - zarówno w kontekście życia samej malarki, jak i życia każdego z nas. To także rozmaite role, jakie zmuszony jest przyjąć człowiek w zależności od sytuacji, w której się znajduje. Autoportret jawi się więc tutaj jako pewnego rodzaju zapis życia, pamiętnik, a zarazem spowiedź artystki. Ten szczególny typ malarstwa, silnie skoncentrowany na psychologicznym i emocjonalnym aspekcie, tak często podejmowany przez Anguissolę, nabiera więc nowego wymiaru i stanowi ponadczasowe przesłanie.

\section{Bibliografia}

Ariosto Ludovico (1928): Orlando furioso. Ed. S. Debenedetti. Bari. Online: https:// it.wikisource.org/wiki/Orlando_furioso_(1928) [dostęp: 19.02.2021].

Borghini Millo (2006): Sofonisba. Una vita per la pittura e la libertà. Milano.

Caroli Flavio (1994): Sofonisba Anguissola e le sue sorelle. Milano.

Chadwick Whitney (2015): Kobiety, sztuka i społeczeństwo. Tłum. E. Hornowska. Poznań.

Costa Patrizia (1999): Sofonisba Anguissola's Self-portrait in the Boston Museum of Fine Arts. Arte Lombarda, Nuova Serie, Nr 125. Online: http://www.jstor.org/stable/43132413 [dostęp: 5.07.2020].

De Tolnay Charles (1941): Sofonisba Anguissola and her relations with Michelango. „Journal of the Walters Art Gallery”, Vol. 4. Online: https://www.jstor.org/ stable/20168754 [dostęp: 2.07.2020].

Gago Baltasar (2020): Galere perdute. Ed. E. Lodi. Milano.

Gamberini Cecilia (2016): Sofonisba Anguissola at the Court of Philip II. In: Women artists in Early Modern Italy. Ed. S. Barkes. Brepols. Online: https:// www.academia.edu/10375100/_Sofonisba_Anguissola_at_the_Court_of_Philip_ II_in_Women_artists_in_Early_Modern_Italy_ed_by_Sheila_Barker_Brepols_2016 [dostęp: 9.07.2020].

Gerrard Mary (1994): Here's Looking at Me: Sofonisba Anguissola and the Problem of the Woman Artist. „Renaissance Quarterly”, No 3. Online: https://www.academia. edu/43811467/Heres_Looking_at_Me_Sofonisba_Anguissola_and_the_Problem_ of_the_Woman_Artist [dostęp: 4.07.2020].

Jacobs Federica (1994): Defining the Renaissance Virtuosa: Women Artists and the Language of Art History and Criticism. Cambridge.

Perlingieri Ilya Sandra (1992): Sofonisba Anguissola: The First Great Woman Artist of the Renaissance. New Jork.

Pinessi Orietta (2008): Sofonisba Anguissola. Milano.

Pizzagalli Daniela (2003): La signora della pittura. Vita di Sofonisba Anguissola, gentildonna e artista nel Rinascimento. Milano.

216

Fabrica Litterarum Polono-Italica | 2021, nr 1 (3) 
Tanzi Marco (2013): Sofonisba tra parenti e infante. In: Il tempo e la rosa. Scritti di storia dell'arte in onore di Loredana Olivato. Ed. P. Artoni, E. Dal Pozzolo [et al.]. Treviso. Online: https://www.academia.edu/31518500/Sofonisba_tra_parenti_e_infante_in_Il_tempo_e_la_rosa_Scritti_di_storia_dellarte_in_onore_di_Loredana_ Olivato_Treviso_2013_pp_180_184 [dostęp: 18.07.2020].

Tanzi Marco (2014): Anguissola family. Online: https://doi.org/10.1093/ gao/9781884446054.article.T003005 [dostęp: 1.07.2020].

Tramelli Barbara: Sofonisba Anguissola, „Pittora de Natura”: A Page from Van Dyck's Italian Sketchbook. Online: https://www.academia.edu/29811820/Sofonisba_Anguissola_ Pittora_de_Natura_A_Page_from_Van_Dyck_s_Italian_Sketchbook?email_work_ card=title [dostęp: 10.08.2020].

Vasari Giorgio (1568): Le vite de' più eccellenti pittori, scultori ed architettori. Firenze. Online: https://it.wikisource.org/wiki/Le_vite_de\%27_pi\%C3\%B9_eccellenti_pittori,_scultori_e_architettori_(1568) [dostęp: 9.07.2020].

\section{Netografia}

Kuiper Kathleen (2009): https://www.britannica.com/biography/SofonisbaAnguissola2009 [dostęp: 3.07.2020].

https://it.wikipedia.org/wiki/Bernardino_Campi_ritrae_Sofonisba_Anguissola [dostęp: 16.07.2020].

https://en.wikipedia.org/wiki/Sofonisba_Anguissola [dostęp: 5.07.2020]. https://it.wikipedia.org/wiki/Sofonisba [dostęp: 6.07.2020].

\section{Abstract}

\section{La pittrice che „ha con più studio e con miglior grazia che altra donna de' tempi nostri faticato dietro alle cose del disegno" Autoritratto di Sofonisba Anguissola}

L'articolo tratta della vita e delle opere di Sofonisba Anguissola - una famosa pittrice italiana del Rinascimento. L'obiettivo è quello di provare a confrontare e analizzare i suoi autoritratti su tre diversi livelli. Il primo livello si concentra su aspetti formali, come composizione, colori o il tema dei ritratti. Il secondo livello uscirà un po' dalla cornice del dipinto e approfondirà la biografia di Sofonisba e gli aspetti culturali, provando a capire le sue opere in quel contesto. Per ultimo, terzo strato cercherà di svelare le proprie motivazioni della pittrice. Di vedere l'artista di quei tempi, attraverso gli occhi di una donna di oggi. Nonostante siano separate da quasi 500 anni, grazie all'eternità dell'arte riescono a stare quasi faccia a faccia, e a provare emozioni simili. Analizzando i suoi autoritratti è possibile vedere le diverse fasi della sua vita: giovinezza, età adulta e anzianità. Ogni ritratto corrisponde a un altro tipo di sensibilità, di aspirazioni e di desideri. Da giovane artista appassionata che sta quasi entrando nella sua vita 
professionale, attraverso una donna matura e sicura di sé, fino a una vecchia matrona soddisfatta, che aspetta la fine della sua vita in pace con se stessa. Sofonisba non solo ha definito lo stile dei ritratti femminili per i prossimi secoli, ma ci ha anche lasciato un diario di ritratti che la documenta in ogni fase della sua vita. Questo specifico tipo di pittura, fortemente incentrato sul riflettere la vera personalità e il carattere di una persona, così spesso intrapreso da Sofonisba, racchiude in sé una nuova dimensione e un messaggio intramontabile.

Parole chiave: Sofonisba Anguissola, rinascimento, pittrice, autoritratto, arte italiana 